Provided for non-commercial research and education use. Not for reproduction, distribution or commercial use.

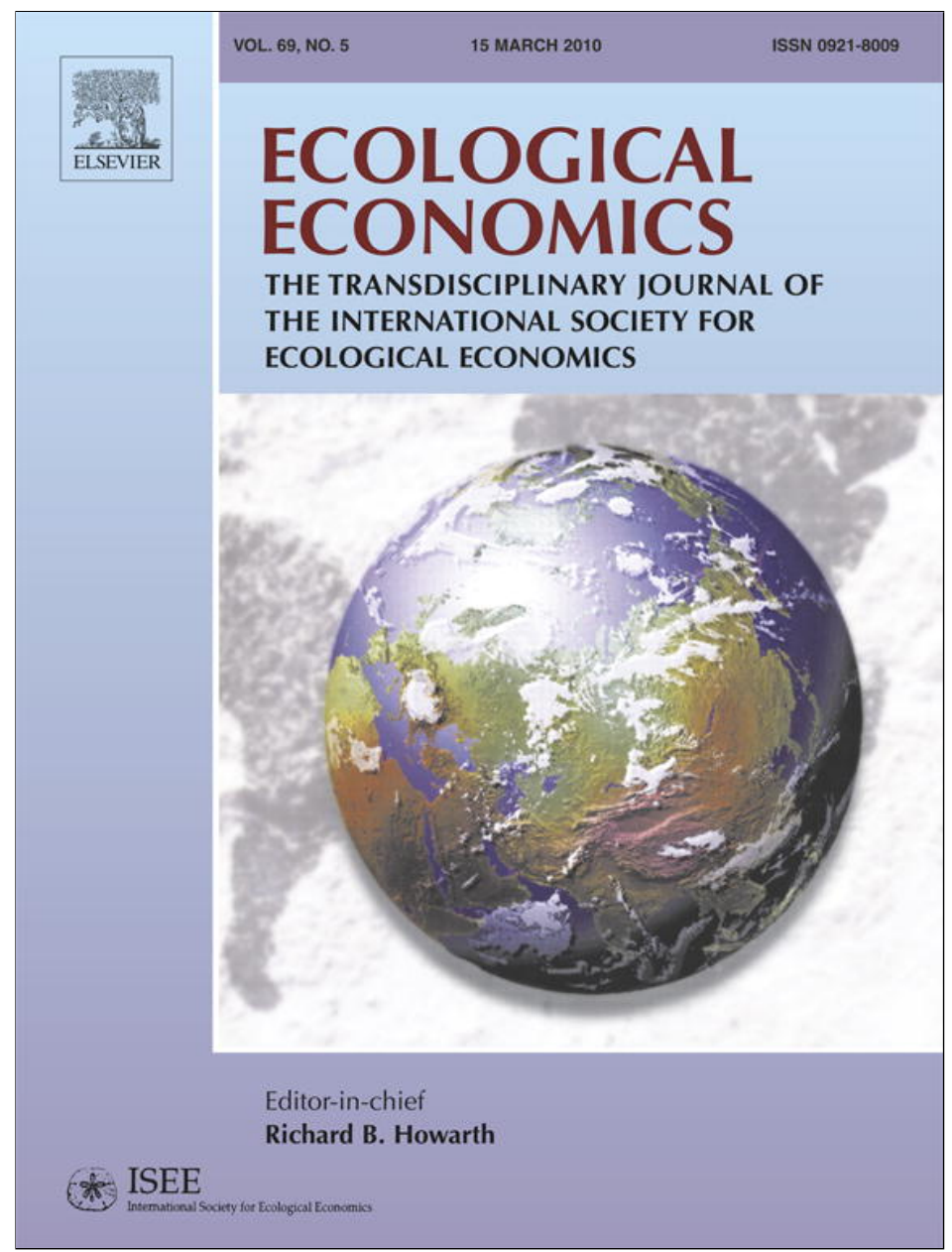

This article appeared in a journal published by Elsevier. The attached copy is furnished to the author for internal non-commercial research and education use, including for instruction at the authors institution and sharing with colleagues.

Other uses, including reproduction and distribution, or selling or licensing copies, or posting to personal, institutional or third party websites are prohibited.

In most cases authors are permitted to post their version of the article (e.g. in Word or Tex form) to their personal website or institutional repository. Authors requiring further information regarding Elsevier's archiving and manuscript policies are encouraged to visit:

http://www.elsevier.com/copyright 
Analysis

\title{
Institutional and ecological interplay for successful self-governance of community-based fisheries
}

\author{
Xavier Basurto ${ }^{\mathrm{a}, \mathrm{c}, *}$, Eric Coleman ${ }^{\mathrm{b}, \mathrm{c}}$ \\ a Duke Marine Lab, Nicholas School of the Environment, Duke University, 135 Duke Marine Lab Road, Beaufort, NC 28516-9721, USA \\ ${ }^{\mathrm{b}}$ Department of Political Science, Florida State University, 113 Collegiate Loop 534 BEL, Tallahassee, FL 32306-2230, USA \\ ${ }^{c}$ Workshop in Political Theory and Policy Analysis, Indiana University, 512 N Park, Bloomington, IN 47408-3895, USA
}

\section{A R T I C L E I N F O}

\section{Article history:}

Received 10 April 2009

Received in revised form 27 October 2009

Accepted 10 December 2009

Available online 13 January 2010

\section{Keywords:}

Common-pool resources

Collective action

Social-ecological systems

Small-scale fisheries

Gulf of California

Mexico

\begin{abstract}
A B S T R A C T
The goal of this paper is to improve our understanding of the role of institutional arrangements and ecological factors that facilitate the emergence and sustainability of successful collective action in small-scale fishing social-ecological systems. Using a modified logistic growth function, we simulate how ecological factors (i.e. carrying capacity) affect small-scale fishing communities with varying degrees of institutional development (i.e. timeliness to adopt new institutions and the degree to which harvesting effort is reduced), in their ability to avoid overexploitation. Our results show that strong and timely institutions are necessary but not sufficient to maintain sustainable harvests over time. The sooner communities adopt institutions, and the stronger the institutions they adopt, the more likely they are to sustain the resource stock. Exactly how timely the institutions must be adopted, and by what amount harvesting effort must be diminished, depends on the ecological carrying capacity of the species at the particular location. Small differences in the carrying capacity between fishing sites, even under scenarios of similar institutional development, greatly affects the likelihood of effective collective action.
\end{abstract}

(c) 2009 Elsevier B.V. All rights reserved.

\section{Introduction}

According to the U. N. Food and Agriculture Organization (FAO, 2006), half of the world's marine fisheries are fully exploited, and a quarter are overexploited or depleted. Indeed, many fisheries and fishing communities around the world are suffering the consequences of overexploitation (Pauly et al., 1998; Jackson et al., 2001; Myers and Worm, 2003; Berkes et al., 2006). However, some well-documented cases of fisheries that have avoided overexploitation are available (Weinstein, 2000; Johannes, 1978, 2002; Acheson, 2003), and an important step forward towards addressing the overfishing crisis is to understand why some communities are able to engage in collective action to avoid overexploitation scenarios.

Towards this goal significant progress has been made in the last twenty years to understand the importance of institutions-understood as the rules, norms, and strategies-that humans use to govern their interactions (North, 2005; Ostrom, 2005) for the management of common-pool resources (CPRs), of which small-scale fisheries are just one example (see the Digital Library of the Commons at http://dlc.dlib. indiana.edu/). Today, the importance of collective action institutions for

\footnotetext{
* Corresponding author. Duke Marine Lab, Nicholas School of the Environment, Duke University, 135 Duke Marine Lab Road, Beaufort, NC 28516-9721, USA.

E-mail addresses: xavier.basurto@duke.edu (X. Basurto), ecoleman@indiana.edu (E. Coleman).
}

the sustainability of CPRs is well established (Ruddle and Johannes, 1985; McCay and Acheson, 1987; Berkes, 1989; Pinkerton, 1989; Ostrom, 1990; National Research Council, 2002; Dietz et al., 2003; Ostrom, 2005; Cinner and Aswani, 2007). It is also well recognized that institutions interact in complex ways with biophysical factors (Berkes and Folke, 1998; Berkes et al., 2006; Berkes, 2005; Orensanz et al., 2005; Liu et al., 2007a,b; Ostrom, 2007). Some initial findings have pointed out that when institutional arrangements are appropriately matched to the biophysical scales in which they are embedded, the probability of successful CPR governance increases (Schlager et al., 1994; Berkes and Folke, 1998; Levin, 1999; Wilson, 2002; Turner et al., 2003; Lansing, 2006; Ostrom, 2007).

A step forward in theory development requires disentangling how institutions and biophysical factors interact in specific settings to facilitate the emergence and sustainability of successful collective action for CPR governance. The goal of this paper is to contribute to the CPR literature in the context of community-based small-scale fisheries in developing countries. We do this by simulating different configurations of institutions and biophysical conditions to show how these factors interact to produce robust or overexploited fishing outcomes.

Such contribution is timely given the rapidly increasing number of community-based projects that advocate the need to build strong local institutions to address a suite of environmental and developmental challenges, without proper assessments of the drivers of success or failure of such initiatives (Mansuri and Rao, 2004). A better understanding of the constraints that resource characteristics place on 


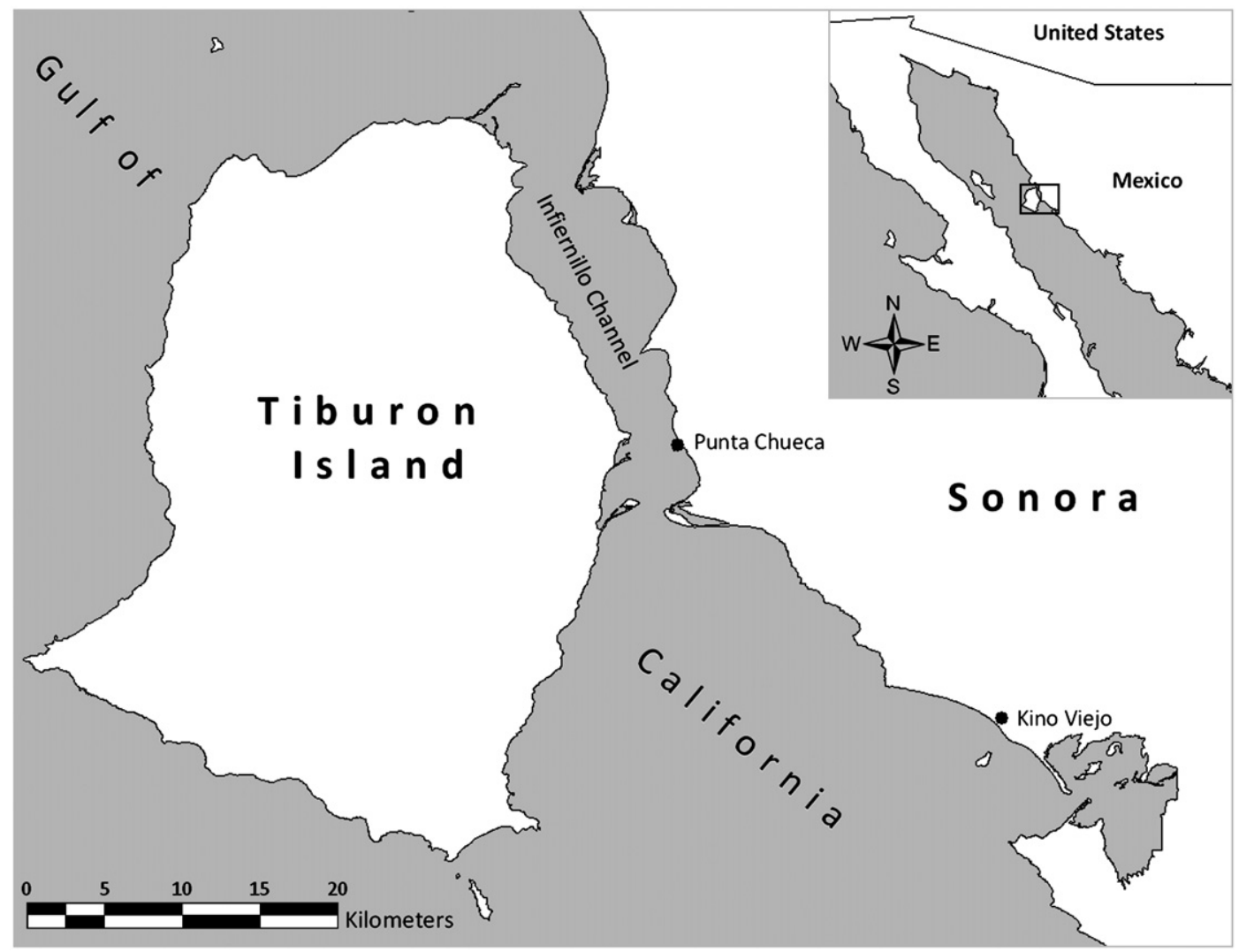

Fig. 1. Location of the Infiernillo Channel, the Seri village (Punta Chueca), and the Kino Viejo village Cartographic design: Nicholas Mallos.

potential governance outcomes can help us understand what outcomes might be reasonable to expect from a given resource system, and allow us to avoid the type of "panacea" policy-making that has dominated common-pool resources governance in the past (for a critique see Ostrom et al., 2007).

In this paper we compare two community-based benthic fisheries in Mexico. At one site, the Seri fishery, community members have successfully engaged in collective action to limit harvesting efforts. This has allowed them to maintain a sustainable harvest for more than two decades. The same did not take place in the other community, the Kino Viejo fishery, and the fishery was overexploited (Moreno et al., 2005b). Additionally, the community that engaged in successful collective action shows a higher ecological carrying capacity in their fishing grounds. The question naturally emerges: Are institutional or ecological factors driving the community's ability to avoid overexploitation? How might both factors be related? We used a modified logistic population growth model to explore how ecological carrying capacity affects communities'like the Seri-ability to avoid overexploitation of their fishing grounds. We accomplish this by simulating communities with varying levels of institutional development, defined as the measure of (a) timeliness, that is how long it takes fishers to adopt new institutions (i.e. engage in successful collective action), and (b) strength, that is the degree to which harvesting efforts are diminished.

In the next section we provide extensive background of the institutional and ecological setting of the Seri fishing community, which we use as an example of successful collective action for avoiding overexploitation of communal fishing grounds, and briefly contrast it with the Kino Viejo neighboring fishing community that has not been able to do the same. We then provide a general model of how institutional arrangements and ecological conditions make contributions to control fishing effort and therefore to the maintenance of an artisanal fishery, such as the one depicted in the Seri case.

\section{Background}

Callos de hacha or pen shells are a very desirable catch for artisanal fishers in the Gulf of California, Mexico, because they are one of the few marine resources with year-round national demand and a constant high market price (Basurto, 2005, 2006). Pen shells are sessile bivalve mollusks-like clams but much larger-that live buried in sandy bottoms. Atrina tuberculosa and Pinna rugosa are the most important pen shell species in the Northern Gulf of California where they are harvested for their edible adductor muscle (Basurto, 2005). Fishers dive to unbury pen shells using a rudimentary underwater breathing apparatus connected through a long hose to an air compressor mounted atop a fiberglass outboard motor boat. Typically a fishing team consists of one or two divers and two or three crewmembers that handle the catch at the surface (Basurto, 2006).

The Seri fishing village of Punta Chueca has avoided overexploitation of the pen shell stock while the neighboring fishing village of Kino Viejo has not. Even though they are located only $30 \mathrm{~km}$ apart from one another (Fig. 1), share the same general ecosystem, harvest the same species and use the same harvesting technology. Evidence for this assertion comes from several sources: comparison of catch per unit of effort (CPUE) in both sites; interviews with fishers on their recollections of historical catches complemented with recent official records of landed catch; underwater surveys to estimate pen shell densities at both sites; and diversification of Kino Viejo catches in response to unsustainable numbers of pen shells year-round.

Data reported by Cinti et al. (2010) through the PANGAS ${ }^{1}$ project fishing log program in 2007 at Kino Viejo fishing grounds showed a lower CPUE (1.1 $\mathrm{kg}$ of adductor muscle/h diving) than that found in 2009 by this

\footnotetext{
${ }^{1}$ The PANGAS project information can be found at http://pangas.arizona.edu.
} 
study at Seri fishing grounds (5.9 $\mathrm{kg}$ of adductor muscle/h diving). ${ }^{2}$ Fishers' reports that Seri fishing grounds are more abundant and "generally doing much better than any other in the region" were confirmed through underwater surveys by Moreno et al. (2005a), who found densities of less than 5 individuals per $300 \mathrm{~m}^{2}$ in most of the Kino Viejo fishing grounds. In comparison, Basurto (unpublished), found an average of 64 individuals per $300 \mathrm{~m}^{2}$ at five important Seri fishing grounds suggesting overexploitation at the Kino Viejo fishing grounds. Interviews on historic catches and landing records of more than $50 \%$ of the fleet during 2009 also suggest that the Seri catch has remained relatively constant for more than two decades, likely fluctuating between 70 and 100 metric tonnes (Basurto, 2005, 2008, and this study). In contrast, statistical data of the Fisheries Office of Kino Viejo, reported by Moreno et al. (2005a,b) show that since 1992 catch in the Kino Viejo community has steadily declined. Production averaged only 20 tonnes per year from 1997 to 2003. ${ }^{3}$ Given that pen shells are one of the few resources with year-round national demand and a constant high market price (Basurto, 2005, 2006), one could expect that fishers would try to remain in this fishery as long as its CPUE outcompetes other available resources. This is certainly the case of the Seri pen shell fishery, where most fishers find it profitable to target pen shells year-round. This is not the case for Kino Viejo fishers who find it more profitable to diversify their catch to include octopus (Octopus spp.), lobsters (Panulirus inflatus), and fish (Groupers: Mycteroperca rosacea and M. jordani; and Snappers: Hoplopagrus guentherii), among others, at different times of the year (Moreno et al., 2005a).

Finally, it has been well documented that the people of the Seri pen shell fishery stand out among other fishing communities in the region for their ability to control access to their fishing grounds (Basurto and Ostrom, 2009). In the following paragraphs we provide a brief comparison of the institutional and ecological context prevalent in the Seri and Kino Viejo fisheries. We mostly focus on describing the Seri's institutional arrangements with which they successfully control access and use to their fishing grounds (Basurto, 2005), and the biological and ecological mechanisms that provide support to their self-governance efforts (Basurto, 2008).

\subsection{A Comparison of Fishing Institutions}

The pen shell fishery is one of many Mexican small-scale fisheries not actively regulated by the federal government and managed by the Seri under a common property regime where fishers have been able to find incentives for conservation (Basurto, 2005). The entire Seri pen shell fishery is located within the Infiernillo Channel, a long (41 km), narrow, and shallow (average depth of $5.5 \mathrm{~m}$ ) body of water that runs south to north and is flanked on the west by Tiburon Island, Mexico's largest, and to the east by the continental coast of the Mexican state of Sonora (see Fig. 1). The Infiernillo Channel constitutes a de facto exclusive fishing zone for Seri fishers.

The Seri have inhabited this coastal area for thousands of years (Felger and Moser, 1985), and the small Seri population is likely a function of hundreds of years of relentless extermination warfare by Spaniards and Mexicans (Sheridan, 1999). ${ }^{4}$ In the 1970s as an effort to guarantee the survival of this small tribal culture and reduce conflicts with other rapidly growing local fishing communities like Kino Viejo, the federal government granted the Seri property rights to a portion of their historic coastal territory (Diario Oficial de la Federación, 1970), Tiburon Island (Diario Oficial de la Federación, 1978), and a fishing concession (Diario Oficial de la Federación, 1975).

\footnotetext{
${ }^{2}$ The estimates for Kino Viejo are based on data provided in two log books from Cerro Prieto fishing site (see Cinti et al., 2010). The estimates for Seri fishing grounds are based on 12 fishing trips conducted by Basurto between January and August 2009

${ }^{3}$ Estimating catch data is extremely difficult for diving fisheries and available official sources likely under-represent catch volume, although they are useful to compare trends overtime.

${ }^{4}$ According to the latest census the population in the Seri village of Punta Chueca is about 300 people (INEGI, 2005) but informal counts suggest around 500.
}

The configuration of the Infiernillo Channel makes it the only section of the fishing concession where the Seri are able to monitor entrance and exit of non-Seri fishermen. The Channel is widely believed to hold the most abundant pen shell banks in the region and the entire Seri pen shell fishery takes place there. Inside the Channel a common property regime has emerged where the Seri have designed a number of rules-inuse with which to grant access and withdrawal rights to outsiders, who then become "authorized users" (Schlager and Ostrom, 1992).

In contrast, Kino Viejo fishing grounds, which mostly span from south of the Infiernillo Channel to the estuary south of Kino Viejo village (see Fig. 1), operate under an open access regime (Cinti et al., 2010; Basurto and Ostrom, 2009). Cinti et al. (2010) found that this is due partly because most fishers cannot participate in collective-choice processes where formal rules to control access to fishing grounds are established. For the most part only fishing permit holders can participate in these processes. Fishing permit holders are not fishers themselves but fish-buyers in control of commercialization channels and have little incentives for conservation. Why most small-scale fishers in Kino Viejo cannot gain access to arenas of institutional design is beyond the scope of this paper and adequately examined in Cinti et al. (2010).

Seri fishers have successfully devised rules to control access across all entry mechanisms to their pen shell fishing areas (Basurto, 2005). These rules determine who is eligible to enter the Infiernillo Channel as an authorized fisher and which areas of the Channel are off limits to authorized entrants. In addition, the Seri have in place a variety of monitoring and enforcement mechanisms to ensure rule compliance. For instance, one rule specifically dictates that for a non-Seri fishing crew to become an "authorized user" to the Infiernillo Channel, a member of the Seri community must be hired as part of the fishing crew. This rule allows granting access rights to generate economic benefits to different members of the Seri community, given that it is customary to share the catch among all the members of the fishing crew. This rule also allows the Seri to monitor-at a low cost to the community-compliance to a rule that dictates that fishers must not fish in culturally important areas. Culturally important areas constitute sandbars in the Infiernillo Channel that are exposed at low tide intervals, allowing manual harvesting without the need of an underwater breathing apparatus. These sites are part of a subsistence practice hundreds of years old, noteworthy for the active participation of members of the Seri community that otherwise cannot participate in the commercial fishery, such as women, children, and elders. The most important sandbar harvesting events occur during the lowest "spring" tides and can become large communal gatherings. ${ }^{5}$ To successfully harvest bivalves in sandbars during spring tides, members of the community must rely on detailed knowledge about when, where, and which sandbars are going to be exposed so that harvesting can take place before the water has covered the sandbars again. This knowledge and their constant presence in the Channel likely allow community members to notice differences in abundance from one harvesting event to the next or observe the presence of unauthorized entrants. If they notice significant or unexpected differences in abundance they usually think (justifiably or not) that commercial divers (that include members of the Seri community and authorized entrants to the fishery) have been harvesting there against communal agreement. Seri commercial fishers in turn frequently blame outside fishermen for the rule violations. When enough uproar about such rule-breaking is created within the community, permits to authorized entrants to the fishery are forfeited-despite authorized entrants' protests-and the overall result is that fishing effort in the Infiernillo Channel decreases (Basurto, 2005). ${ }^{6}$

${ }^{5}$ In the spring tide of March 29th 2009, more than 14 different Seri families gathered along the Infiernillo Channel to harvest from sandbars (Alberto Mellado personal comment 2009).

${ }^{6}$ Sandbar harvesting is only one of several different ways by which the Seri community is able to monitor and enforce fishing activities inside of the Infiernillo Channel (Basurto field observations 2009). 


\subsection{A Comparison of the Ecological Systems}

Broadly speaking, the ecological systems where the Seri and Kino Viejo's fisheries take place are similar except in one important regard: The most extensive meadows of eelgrass Zostera marina in Western Mexico are located in Seri fishing grounds (Felger and Moser, 1985), while eelgrass meadows are essentially absent in Kino Viejo fishing grounds (Torre-Cosío, 2002). Torre-Cosío (2002) argued that the large extent of eelgrass inside the Infiernillo Channel is due to the long eelgrass life cycle in comparison to other areas in the Gulf of California and to its shallow depths and particular current patterns, which also contribute to keep seeds in the same areas, determining the stability and distributional patterns of eelgrass beds. These favorable biophysical characteristics are absent in Kino Viejo fishing grounds, which help explain eelgrasses limited spatial and temporal presence there. The extent of the presence of eelgrass meadows in each fishery plays an important role in each fishery's carrying capacity, as we describe next.

At the time of the maximum coverage $Z$. marina occupies up to $12 \%$ of the Channel's bottom, and throughout the eight months that eelgrasses are present in the Channel distinct pen shell beds are covered and out of reach for harvesting (Torre-Cosío, 2002). Indeed, researchers have found pen shells associated to eelgrass meadows elsewhere (Richardson et al., 1999), and divers in the Infiernillo Channel consistently state that they do not like to harvest pen shells in areas covered by marine plants because the visibility is poor, making the work more cumbersome and increasing the risk of stepping on a sting ray or swimming crab. As a result, fishers mostly restrict their use to pen shell fishing grounds where marine meadows are not present. This, in turn, assures that a portion of the fishing stock remains off limits to the Seri fishery at different times of the year. This is not the case in Kino Viejo fishing grounds where pen shells are accessible to fishers year-round given the very limited presence of $Z$. marina. In sum, eelgrass meadows effectively create non-fishing areas in the Channel that likely play an overall positive role on the regeneration of the Seri fishing stock and increasing the overall carrying capacity of the Channel as compared to other pen shell fishing areas outside of it, e.g. Kino Viejo.

In addition to the presence of eelgrass meadows, there are other factors-related to the particularities of the biology of the pen shellsthat also seem to provide buffering capabilities to the pen shell population against perturbations like non-stop harvesting efforts. For instance, fishers can shape their catch based on their ability to distinguish by species, size, and fishing area location, before unburying pen shells from the bottom (Basurto, 2008). None of these characteristics seem to be correlated to the reproductive cycle of the pen shells. As a result, fishers' individual day-to-day harvesting decisions are not likely to have an immediate impact on the reproductive viability of the pen shell population. In addition, fishers cannot distinguish males from females by looking at the shell or the adductor muscle meat alone, and shell or adductor muscle meat size, do not seem correlated to sexual dimorphism (Basurto, 2008). Moreover, the spatial distribution of the sexual ratio is a 1 to 1 relationship for males and females (Ahumada-Sempoal et al., 2002; Moreno et al., 2005b; Basurto, 2008). This prevents more concentrated harvests of one sex over the other that otherwise could potentially harm the reproductive viability of the species if they were to be spatially differentiated by sex. Finally, pen shells rapid growth and sexual maturation rate at one year of age (Angel-Pérez et al., 2007), result in that more than $70 \%$ of the harvests in the Infiernillo Channel are more than one year old (Basurto, 2008), indicating that most of them have already spawned at least once before being harvested. In sum, the presence of eelgrass meadows and the particularities of the reproductive characteristics of the species harvested, make reasonable to think that biological and ecological factors might be able to provide resilience to the Seri fishery for longer periods of time, than in other settings where biological and ecological conditions might be entirely different. ${ }^{7}$

Finally, and to summarize, the Seri fishery is similar to other benthic fisheries in the region like Kino Viejo in that harvesters use the same harvesting technology and target the same species of pen shells. The Seri shows two striking differences, however. The Seri were able to develop strong institutional arrangements to control access to non-community members while other open access fisheries like Kino Viejo were not able to develop institutional capacity. Second, only the Seri fishing grounds have extensive marine vegetation patches covering pen shell beds-effectively increasing the carrying capacity of their fishery. So the question remains: What is the role of ecological factors in cases like the Seri, where the community has been able to engage and sustain collective action for the benefit of their fishery?

In the next section we develop a general model to show how institutional capacity and ecological factors might be related to communal ability to avoid overexploitation. We do so by simulating varying institutional and ecological conditions on a logistic population growth model, modified to allow for a minimum viable population. We find that strong and timely institutions are necessary but not sufficient to develop and maintain a fishing system like the Seri over time. Even when holding institutional capacity constant across communities, we show that small differences of ecological carrying capacity can greatly affect the ability of fishers to engage in successful collective action.

\section{Model Description}

We evaluate how differences in ecological conditions influence the propensity of effective institutions to emerge. To do so, we develop a logistic population growth model, allowing for a minimum population threshold. ${ }^{8}$ First, consider two different populations, $x$ and $y$ of the same species. The populations differ only in the constraints their environment places on their growth through differences in carrying capacity. The growth of these two populations is expressed by the equations below.

$$
\begin{aligned}
& \frac{d x}{d t}=-r\left(1-\frac{x}{M}\right)\left(1-\frac{x}{K_{x}}\right) x-E x \\
& \frac{d y}{d t}=-r\left(1-\frac{y}{M}\right)\left(1-\frac{y}{K_{y}}\right) y-E y
\end{aligned}
$$

The parameter $r$ is the intrinsic growth rate of the species and is determined by its specific biological reproduction, growth, and mortality rates. The parameter $M$ represents the minimum viable population for the species, and the parameter $E$ represents the aggregate fishing effort. This fishing effort is interpreted as rate of harvest, or the proportion of harvested fish stock. We assume fishing effort is the same at both sites. Upon first discovery of the resource, the harvesters have little biological information upon which to base their effort decisions. Only through a trial-and-error process do the harvesters adjust their fishing effort. This process will be discussed below.

The parameters $K_{x}$ and $K_{y}$ represent each population's carrying capacity. We assume that these carrying capacities are not equal; that is, the specific ecological characteristics at each site allow for

\footnotetext{
7 Take for instance, many species of groupers, that have been quickly overfished because all harvesting takes place when they aggregate to mate (Sala et al., 2001). Similarly, species that have low growth, fecundity, and maturation rates (i.e. rays and sharks) are particularly susceptible to overexploitation (Bizzarro et al., 2007).

${ }^{8}$ For a discussion of logistic growth models, see Boyce and Durpia (2001). The model incorporating both species thresholds and logistic growth is known as the Schaeffer Model. This model is a Schaeffer Model with an added harvesting function.
} 


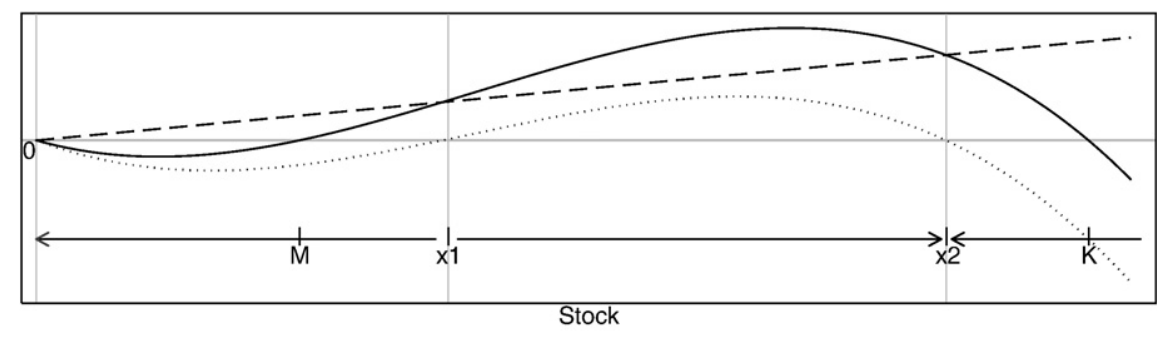

- Growth - - - Harvest …......... Net Growth

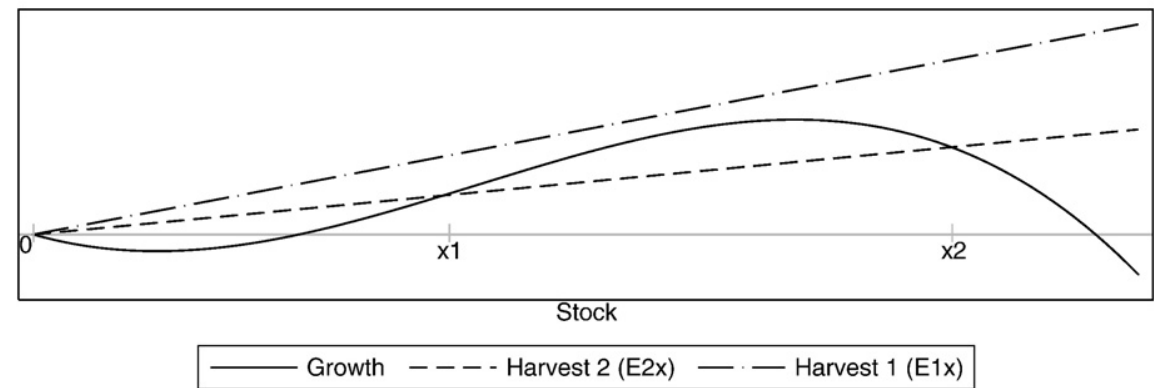

Fig. 2. A graphical depiction of the fishery model. The top panel shows the biological growth function for the species, total harvest with a harvest rate proportional to the fish stock, and the net growth of the stock. There are two stable equilibria in the system, at point $x 2$ and 0 . The bottom panel shows the biological growth function, and two different harvesting rates. With the first harvest rate $\left(E^{1}\right)$ the only stable equilibrium is at a stock of 0 . With the second harvest rate $\left(E^{2}\right)$ there are two stable equilibria in the system, at point $x 2$ and 0 .

differences in the size of carrying capacity. Suppose further that the environmental conditions at the site for population $x$ allow for a higher carrying capacity than the conditions at the site for population $y$ so that $K_{x}>K_{y}$.

This model, while not a perfect representation of the population growth, has a number of desirable properties including the fact that the rate of growth depends on the size of the population. Growth is constrained by the carrying capacity of the environment, $K$. The species is also susceptible to overexploitation and will crash if the species drops below its minimum viable population, $M$.

The top panel of Fig. 2 shows a phase diagram derived from Eq. (1) and Eq. (2). Along the horizontal axis the population is measured and along the vertical axis the rate of growth of the population is reported. There are two parts to the net growth rate of the population: the natural growth rate, $-r\left(1-\frac{x}{M}\right)\left(1-\frac{x}{K_{x}}\right) x$, and human harvesting Ex. Each of these is separately plotted in the top panel of Fig. 2, along with a curve indicating net growth of the population which subtracts harvesting from the biological growth. There are three equilibria for this model. An equilibrium refers to a case where the net growth rate of the population is zero. The first equilibrium is where the population is equal to zero; this equilibrium is stable. This can be seen by imagining what would happen if a few individuals were introduced to population $x$ when the population is zero, but not enough to move beyond the minimum viable population. Fish growth would be negative, because the population would be below the minimum viable population. Positive harvesting would further cause the population to decline and eventually the population would return to zero.

At point $x 1$ there is another equilibrium, but this is not stable. At this point, any slight perturbation that would cause the population to decline would move the population to something slightly left of $x 1$. If this happens, the growth rate is less than the amount harvested and the population will continue to decline until the population reaches zero and is stable. On the other hand, if there is a slight perturbation that causes the population to increase, the growth rate of the population will exceed the harvest rate and so the population will continue to grow until it converges to point $x 2$.

The final equilibrium is at point $x 2$. Here, any perturbation that causes the population to decline will result in a situation where the growth rate of the fish stock exceeds the harvest rate; thus, the population will increase. If there is a perturbation such that the population increases, the harvest rate will exceed the growth rate and the population will return to point $x 2$. $^{9}$

Next, contrast two harvesting regimes, where the aggregate level of effort in the first regime is $E^{1}$ and in the second regime is $E^{2}$. Note that the level of effort is the same at both sites, $x$ and $y$. The shift in regime (the superscript) refers to a change in time. We assume that upon first discovery of the fishing sites, locals have a high level of effort and that during the second regime this level of effort diminishes so that $E^{1}>E^{2}$. This assumption implies that harvesters are prone to overexploitation of the population in early time periods, but that they have the ability to change this behavior after some time. Much research shows that local resource harvesters are able to act collectively to reduce harvesting effort (Ostrom, 1990). The exact degree to which a community of harvesters is able to reduce effort, and how quickly they are able to do so, will be modeled below. We introduce a parameter $\tau$, to measure how much time the community takes to switch to the low effort regime.

The relative harvesting efforts $E^{1}$ and $E^{2}$, represent how strong the institutions are. That is, if $E^{2}$ is much lower than $E^{1}$, then harvesting effort is strongly reduced. We first assume that the level of effort during the first regime is very large, so that the harvest rate exceeds the rate of growth of the fish population at all levels. ${ }^{10}$ We also assume that humans at both sites are eventually able to change regimes sufficiently so that, at least in some circumstances, they are able to attain a non-zero equilibrium level of harvesting. The formal condition for these assumptions is found in Eq. (3). (See the Appendix A for a derivation of this condition.)

$$
E^{1}>\frac{\left(K_{y}-M\right)^{2} r}{4 K_{y} M}>E^{2}
$$

To gain a grasp of the intuition of the model, we depict the regime change in bottom panel of Fig. 2. In the first regime, the harvest effort

\footnotetext{
${ }^{9}$ Note that the specific values of $x 1$ and $x 2$ can be found by setting the harvest rate equal to the biological growth rate. Specifically $x_{1,2}=\frac{r\left(M-K_{x}\right) \pm \sqrt{\left(K_{x} r-M_{r}\right)^{2}-4 r K_{x} M(E+r)}}{2 r}$

10 This is not an unreasonable assumption, as much empirical evidence indicates that many fisheries have high rates of harvesting causing them to be overexploited (Pauly et al., 1998; Jackson et al., 2001; Myers and Worm, 2003; Berkes et al., 2006).
} 
is $E^{1}$ and the total harvest is $E^{1} x$. In the second regime the harvest effort is $E^{2}$ and the total harvest is $E^{2} x$. Note that in the first regime, $E^{1}$ is so large that more is being harvested at every level of the population, than can be replenished by the species. If this continues indefinitely, then the population will converge to the only single steady state equilibrium at a population of zero. The second regime, however, has a more modest harvesting effort and is analogous to the case in the top panel of Fig. 2, in that there exists a non-zero stable equilibrium at point $x 2$. If the fish stock at the end of the first regime is greater than $x 1$, then the fishery will rebound and reach this steady state equilibrium at $x 2$. That is, the fish stock will only rebound if during the first regime the fish stock has not been depleted beyond $x 1$.

We assume that $\tau$, the time until regime change, is the same in each population. The determinants of $\tau$ are largely institutional. If two communities are similar in culture and other important sociological aspects it is reasonable to assume that their institutional capacity is similar. In other words, if the human dimensions of the socioecological system are similar across fishing sites, then it may be reasonable to assume that the time needed to adopt new institutions, and the relative strength of these institutions, will be similar as well.

The next step in the modeling effort is to apply site-specific environmental constraints and assume the same institutional capacity (i.e. the time to adopt lower harvesting efforts, and the magnitude of those efforts are the same across sites) while holding all else constant. The only difference across sites is the fact that environmental conditions at one site are more favorable than those at another (manifested in different carrying capacities). In other words, we will now show that communities with the same institutional capacity, managing the same species, can have very different environmental outcomes if the local environment allows for a different carrying capacity.

\section{Simulation Results}

To analyze the model from the preceding section, it is useful to do simulations to show how different outcomes might occur given the model parameters. The simulation exercise is calibrated using known species parameters from the Pinnidae mollusks harvested in the Seri and Kino Viejo fishing communities. ${ }^{11}$ The carrying capacity parameters are normalized so that the carrying capacity at site $x, K_{x}$, is at $100 \%$ of capacity, while the carrying capacity at site $y, K_{y}$ is assumed to be less.

Table 1 lists the assumed parameter values for the simulation results reported in Table 2. As noted, site $x$ is assumed to have a full carrying capacity and thus takes a value of 100 . Environmental factors at site $y$, however, limit the carrying capacity to 80 . Also, we assume that the minimum viable population at both sites is equal to one fourth of the carrying capacity at site $x$. The intrinsic rate of growth is assumed to be 0.4 . The rate of growth is taken from the upper end measured by Garcia-March et al. (2007) from Pinna nobilis found in the western Mediterranean Sea. This species is closely related to the Pinnidaes A. tuberculosa and P. rugosa, harvested by the Seri and Kino Viejo communities, and similar in that it also shows a high growth rate. We choose the upper end of growth rates measured from that study as a conservative estimate for our model. See also Katsanevakis (2007).

We assume that the initial stock of mollusk is equal to the sites' carrying capacity. Absent human intervention, this is the only nonzero stable equilibrium. Thus, before human contact one would expect the stocking level to be approximately equal to the carrying capacity.

We vary the levels of effort, the proportion of the stock that is harvested, in the different regimes to test the robustness of our results to the strength and timeliness of institutional adaptation. The value of

\footnotetext{
11 While these two fishing communities are of very different ethnic and historic origin, when it comes to fishing Pinnidaes they both share a common fishing culture and history. For a more in-depth description see Basurto (2006).
}

$E^{2}$ represents the harvesting effort in the second regime, or the proportion of the fish stock that is caught each year. If this harvesting effort is low compared to the harvesting effort in the first regime, we say that the institutions are strong. In our simulations, the initial harvest rate is 0.25 . We define strong institutions as those for which the subsequent harvest rate is 0.05 , or a decrease in harvesting effort of $80 \%$. Institutions must be timely enough so that they are implemented before the stock falls below the minimum threshold and collapses. The $\tau$ parameter is used to show the effects of timeliness. We consider cases for which institutions are adopted 5 , 10,15 , or 20 years after initial harvesting.

Table 2 shows simulation results for Eqs. (1) and (2) using the assumed parameter values reported in Table 1 . Note that the designation "Crash" reported in Table 2 means that the population approaches zero as time increases. In parentheses we have included the number of years after which the population is less than 1 .

When interpreting these simulations the reader should keep in mind that the results are related to the two fishing communities discussed in Section 2. In Section 2 we argued that the ecological characteristics of the Seri pen shell fishery allow for a greater carrying capacity than at Kino Viejo. The purpose of the simulation is to model how ecological differences in carrying capacity might affect the ability to maintain fishing harvests over time. In this spirit, we interpret site $x$ of the simulation model to reflect the conditions at the Seri fishery, while we interpret site $y$ of the simulation model to reflect the condition at the Kino Viejo fishery. Following the model assumptions, we assert that the capacity to adopt strong and timely institutions at the two case-sites is similar. Our discussion of the simulation results, then, should be interpreted to reflect how similar institutional arrangements have variable environmental outcomes because of initial differences in carrying capacity. These two sites provide one example of such a situation.

\section{Discussion}

There are at least four points to note from the simulation. First, is the important role of the effect of differences in carrying capacity. It is clear that site $y$ crashes under a greater number of scenarios than site $x$. Take, for example, the moderate institutions case in Table 2. Here, harvesting effort declines by $60 \%$ (harvesting declines from $25 \%$ of the fish stock per year to $10 \%$ of the fish stock per year). If it takes both communities 10 years to adopt this moderate institution, then site $x$ will recover, while site $y$ will crash after 15 years. This is driven completely by the differences in carrying capacity at the two sites, as the reduction in harvesting rate, time to adoption of the new institutions, and all else are constant across sites. This implies that two different fishing communities, differentiated solely by the environments' carrying capacity, and adopting the same institutions within the same time frame may have very different results. At site $y$, the biophysical environment will simply not support a 10 year time frame to adopt moderate institutions, while site $x$ will.

Second, both aspects of institutional development are important. Even with strong institutions (harvesting effort severely reduced) the simulation results indicate that institutions must be adopted within a reasonable time frame or both populations may crash. Even when site $y$ adopts institutions in 10 years the population crashes under every

Table 1

Assumed parameter values.

\begin{tabular}{lll}
\hline Parameter & Value & Description \\
\hline$K_{x}$ & 100 & Carrying capacity at site $x$ \\
$K_{y}$ & 80 & Carrying capacity at site $y$ \\
$x(0)$ & 100 & Initial stock at site $x$ \\
$y(0)$ & 80 & Initial stock at site $y$ \\
$M$ & 25 & Minimum viable population \\
$r$ & 0.4 & Rate of growth of $A$. tuberculosa (annual) \\
\hline
\end{tabular}


Table 2

Simulation results

\begin{tabular}{|c|c|c|c|c|c|}
\hline Label & $E^{1}$ & $E^{2}$ & $\tau$ & Site $x$ result & Site $y$ result \\
\hline \multirow{4}{*}{ Moderate institutions ( $60 \%$ less harvesting effort) } & 0.25 & 0.1 & 5 & Recover & Recover \\
\hline & 0.25 & 0.1 & 10 & Recover & Crash ( 15 years) ${ }^{a}$ \\
\hline & 0.25 & 0.1 & 15 & Recover & Crash $(13 \text { years })^{a}$ \\
\hline & 0.25 & 0.1 & 20 & Crash $(29 \text { years })^{a}$ & Crash (13 years) ${ }^{a}$ \\
\hline \multirow{4}{*}{ Strong institutions (80\% less harvesting effort) } & 0.25 & 0.05 & 5 & Recover & Recover \\
\hline & 0.25 & 0.05 & 10 & Recover & Crash (16 years) ${ }^{a}$ \\
\hline & 0.25 & 0.05 & 15 & Recover & Crash $(13 \text { years })^{a}$ \\
\hline & 0.25 & 0.05 & 20 & Crash (32 years) ${ }^{a}$ & Crash (13 years) ${ }^{a}$ \\
\hline \multirow[t]{4}{*}{ Weak institutions (20\% less harvesting effort) } & 0.25 & 0.2 & 5 & Recover & Crash (15 years) ${ }^{a}$ \\
\hline & 0.25 & 0.2 & 10 & Recover & Crash ( 14 years) ${ }^{a}$ \\
\hline & 0.25 & 0.2 & 15 & Crash (31 years) ${ }^{a}$ & Crash $(13 \text { years })^{a}$ \\
\hline & 0.25 & 0.2 & 20 & Crash (27 years) ${ }^{a}$ & Crash (13 years) ${ }^{a}$ \\
\hline
\end{tabular}

a Year at which the stock is less than 1.

scenario. At site $x$, the community must adopt institutions before 20 years or it will eventually collapse despite the strength of the institutions it adopts. Also, if both sites adopt even moderate institutions within 5 years, both sites will maintain a sustainable harvest. Only at site $y$ when weak institutions are implemented, although quickly adopted (within 5 years) institutions fail to sustain the resource.
Institutional strength is especially important for site $y$, which always crashes if it adopts weak institutions (reduced harvesting by only $20 \%$ ), independent of how quickly it is able to adopt them. From this simulation it appears that at site $x$, with better biophysical conditions, continued sustainable harvests are less sensitive to the strength of the institutions; it is more important that they are adopted

\section{Institutional Strength}
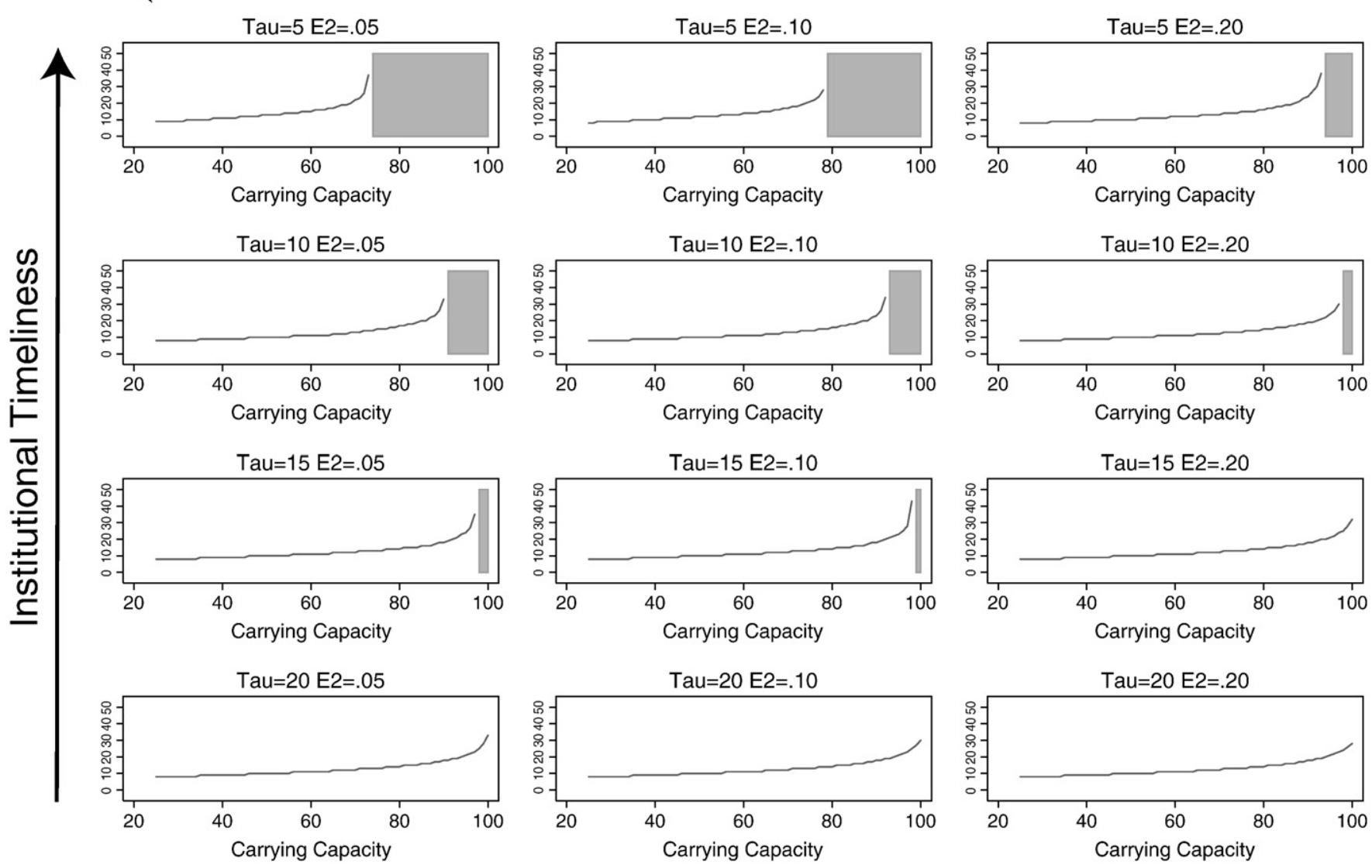

$\mathrm{Tau}=20 \mathrm{E} 2=.20$

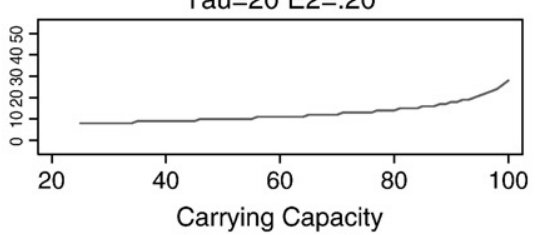

\section{Time to Crash}

\section{Sustainable}

Fig. 3. Sensitivity analysis of the fishery model. Each panel shows the time to which the fishery collapses (population less than 1), if it collapses, and the sustainable regions of carrying capacity. The shaded areas indicated that for the assumed parameter values, fisheries with carrying capacities within the range of the shaded areas will be sustained. The three columns differ in institutional strength; in the first column, strong institutions are adopted $\left(E^{2}=0.05\right)$, in the second column moderate institutions are adopted $\left(E^{2}=0.10\right)$, and in the third column weak institutions are adopted $\left(E^{2}=0.20\right)$. Each of the rows differ in the timeliness of institutions adopted; in the first row institutions are adopted in 5 years, in the second row 10 years, in the third row 15 years, and in the fourth row 20 years. The strongest and most timely institutions are in the upper left corner. The weakest and most untimely institutions are in the bottom right corner. 
quickly. In fact, this appears to be the strategy taken by the fishers from the Seri community, the community comparable to site $x .{ }^{12}$

Third, our simulation results also showed that the more timely and stronger the institutions, the longer the community can continue harvesting, even if the fishery ultimately crashes. Institutional adoption delays the time to collapse and provides resources over a longer time period. Furthermore, even if the institutions are unsuccessful at maintaining long-term harvests for that specific fishery they may provide a foundation for cooperation in future endeavors, especially if local actors are able to transfer these relations to other interaction arenas, whether they are related to fishing or not. Thus, even if fishing institutions ultimately fail, they may play an important role in building trust and reciprocity ties among community members.

Fourth, it is worth mentioning that if the two sites adopt the same strength of institutions, within the same time frame, one site might be able to sustain the fishery while the other might fail, simply because the carrying capacity is different. It is important to note that differences in carrying capacity are not greatly exaggerated in this example. The carrying capacity at the disadvantaged site is assumed to be $80 \%$ of the carrying capacity of the other site. If carrying capacity differs even more (if the carrying capacity is even lower in the disadvantaged site), as is apt to be the case between the Seri and Kino Viejo fishing areas, then the outlook is even bleaker to disadvantaged sites (see Fig. 3 ). ${ }^{13}$ That is, when comparing two sites with drastically different carrying capacities, it is unrealistic to believe that the site with poor carrying capacity will be able to erect and maintain local institutions that would sustain a similar fishing effort to the site with a higher carrying capacity. Students of collective action need to be particularly careful when assessing the effects of a given institution, because underlying ecological conditions can greatly modify the efficacy of institutions. Some of the core problems of environmental policy analysis lie in showing that institutions cause or can modify an environmental outcome, and our analysis suggests a complex, interactive effect between institutions and ecological factors. Analysts of environmental policy and ecological economics should be careful to model and explain these interactions before concluding that institutions are or are not effective (Young, 2002).

\section{Conclusions}

Our paper has shown the role that even small differences in ecological factors (i.e. carrying capacity) can play in communities' ability to create or

\footnotetext{
12 Asking Seri fisher informants about the timing and process by which institutions to control fishing effort emerged in the Seri community corroborated this finding. Interviewees consistently indicated that institutions emerged very quickly in the face of a perceived external threat. Fishing effort for pen shells spiked up in the mid 1980s (the fishery started around 1978) as a result of the overexploitation of other more easily available valuable fish species (Basurto, 2006). The increased presence of outsiders on Seri fishing grounds prompted a strong and prominent Seri leader to quickly enact two important rules to control access to fishing grounds inside the Channel: a) That outsiders needed to pay for a fishing permit and that b) a member of the community must become part of the fishing crew. Our interviews also suggest that there was no formal collective-choice process involved in the enactment of these rules in the sense of having communal gatherings to make consensus-based decisions, as this would be foreign to Seri decision-making practices. Among the Seri discussions and collective-choice process take place through informal gatherings in small groups with fellow fishers and neighbors. The fact that these rules became immediately accepted and viewed as legitimate by the Seri community speaks to the leader's legitimacy on the eyes of fellow communal members, and to the pragmatic fact that these rules brought clear short-term benefits to many members of the Seri community in the form of monetary income (see Basurto, 2005).

${ }^{13}$ We also examined the robustness of our results when varying the carrying capacity at the disadvantaged sites. We analyzed time to failure given values of the initial carrying capacity ranging from the minimum viable population (25) up to the full carrying capacity (100). A summary of these results is presented in Fig. 3. These results show that fisheries with larger carrying capacities are more likely to have sustainable harvests the stronger and more timely the institutions. Fisheries with smaller carrying capacities are also more likely to have sustainable harvests with strong, timely institutions. Carrying capacity, however, is limiting in many instances; that is, low carrying capacities often imply that even timely and strong institutions will not successfully sustain fishing harvests.
}

sustain successful collective action overtime. Given the increased importance that community-based initiatives have taken as a policy tool to address environmental and social dilemmas, it is paramount to develop a better understanding of the constraints that resource characteristics place on potential governance outcomes. If we fail to provide empiricallysupported data of conditions under which communities might succeed or fail to develop robust local institutions for the governance of their CPRs overtime, we risk the chance that these institutions, no matter how welldesigned, cannot perform well given the ecological constraints at a particular site. Supporting the formation of strong local institutions is no panacea for sustainability. In many instances local institutions cannot do it alone (Cudney-Bueno and Basurto, 2009).

Our findings also suggest that initial endowments of natural capital are critical for the emergence and later sustainability of collective action. In other words, the resilience of the CPR, through elevated levels of ecological carrying capacity, might provide fishers with crucial time to learn-by-doing, gain trust with one another, and develop other basic ingredients that are thought to increase the likelihood that successful collective action will emerge (Ostrom, 2005). Consider the 30 year old Seri pen shell fishery. It undoubtedly took some time before the harvesting of pen shells in the Infiernillo Channel reached its current levels. Before the mid 1980s it is likely that it was not necessary for the Seri to have institutions in place to maintain their fishing system. The possibility of maintaining a constantly increasing trend of harvesting rates by ecological factors alone, could have allowed Seri fishers time to learn about the system and develop some understanding of how different institutional arrangements for controlling access and use to their resources might work out if instituted. When it became necessary to develop a rule system to control fishing effort-because outsiders' pressure to gain access to the Channel increased-the Seri had a fairly good idea of which rules might work and which ones might not, and quickly moved to enact such a rule system. Once in place, the socialecological system's ability to buffer likely spikes of fishing effort at particular moments of time (no rule system is perfectly enforced all the time), likely contributed to fishers' continued ability to learn how their chosen rule-set performed, creating the opportunity to adjust accordingly. At the Kino Viejo site, however, fishers were probably not afforded the same luxury. With persistently high levels of harvesting, given the limitations of the resource system, only timely, strong institutions may have been sufficient to sustain the fishery.

In other words, we conclude that without the ability to explore different rule systems before sending their marine resources into a rapid trajectory of collapse, fishers would not be able to collectively learn from one another's experiences, negotiate, and agree to find ways in which to implement those institutional arrangements that best fit their particular circumstance. Clearly, future studies are needed of other small-scale fishing communities in developing countries that systematically collect data overtime about collective action processes and the ecological factors in which these processes take place.

\section{Acknowledgements}

Our thanks go to the Christensen Fund and the Workshop in Political Theory and Policy Analysis at Indiana University for financial and logistical support. Alberto Mellado and Humberto Romero, members of the Seri or Comcáac community, provided excellent field data collection assistance. Jim Wilson, Marco Janssen, Jimmy Walker, Ester Blanco and two anonymous reviewers offered valuable suggestions to improve the quality of this manuscript.

\section{Appendix A}

To find the critical value, note that fishing effort in the first regime must result in a harvest such that the total amount harvested exceeds the natural rate of growth for all levels of the fish stock. In the second regime, for at least some levels of the fish stock, the natural rate of 
growth must exceed the total amount harvested. The critical value is where the total amount harvested resulting from the maximum effort $E^{*}$ is just equal to the natural growth rate. In other words, we want to find the stocking level at which the harvest effort is maximized and yet the total harvest equals the natural rate of growth of the fish stock. Eq. (A1) reports the maximization problem.

$\operatorname{Max}: E^{*}=-r\left(1-\frac{y}{M}\right)\left(1-\frac{y}{K_{y}}\right)$

Maximizing with respect to $y$ we obtain the following result.

$\frac{\partial E^{*}}{\partial y}=0 \rightarrow y=\frac{K_{y}+M}{2}$

Inserting $y$ to solve for the maximum effort yields the following result.

$E^{*}=\frac{\left(K_{y}-M\right)^{2} r}{4 K_{y} M}$

At levels of effort greater than $E^{*}$ the fishery cannot be maintained, as the total human harvest would exceed the natural growth rate at all levels of the fish stock. At levels of effort less than $E^{*}$, at least in some ranges of the fish stock, the natural rate of growth exceeds the total human harvest and there exists a non-zero stable equilibrium.

\section{References}

Acheson, J.M., 2003. Capturing the Commons. Devising Institutions to Manage the Main Lobster Industry. University Press of New England, Hannover, New England, USA.

Ahumada-Sempoal, M.A., Serrano-Guzmán, S.J., Ruiz-García, N., 2002. Abundancia, estructura poblacional y crecimiento de Atrina maura (Bivalvia: Pinnidae) en una laguna costera tropical del Pacífico mexicano. Revista de Biologia Tropical. 50 (3/4), 1091-1100.

Angel-Pérez, C., Serrano-Guzmán, S.J., Ahumada-Sempoal, M.A., 2007. Ciclo reproductivo del molusco Atrina maura (Pterioidea: Pinnidae) en un sistema laguna costero, al sur del Pacífico tropical mexicano. Revista de Biologia Tropical. 55 (3/4), 839-852.

Basurto, X., 2005. How locally designed access and use controls can prevent the tragedy of the commons in a Mexican small-scale fishing community. Journal of Society and Natural Resources. 18, 643-659.

Basurto, X., 2006. Commercial diving and the callo de hacha fishery in Seri territory. Journal of the Southwest. 48 (2), 189-209.

Basurto, X., 2008. Biological and ecological mechanisms supporting marine self-governance: the Seri callo de hacha fishery in Mexico. Ecology and Society 13 (2), 20 online] http:// www.ecologyandsociety.org/vol13/iss2/art20/.

Basurto, X., Ostrom, E., 2009. Beyond the tragedy of the commons. Economia delle font de energia e dell' ambiente 52 (1), 35-60.

Berkes, F. (Ed.), 1989. Common Property Resources. Ecology And Community-Based Sustainable Development. Belhaven Press, London, UK

Berkes, F., 2005. Commons theory for marine resource management in a complex world. Senri Ethnological Studies 67, 13-31.

Berkes, F., Folke, C. (Eds.), 1998. Linking Social and Ecological Systems. Management Practices and Social Mechanisms for Building Resilience. Cambridge University Press, Cambridge, UK.

Berkes, F., Hughes, T.P., Steneck, R.S., Wilson, J.A., Bellwood, D.R., Crona, B., Folke, C., Gunderson, L.H., Leslie, H.M., Norberg, J., Nyström, M., Olsson, P., Österblom, H. Scheffer, M., Worm, B., 2006. Globalization, roving bandits, and marine resources. Science 311 (17), 1557-1558.

Bizzarro, J.J., Smith, W.D., Márquez-Farías, J.F., Hueter, R.E., 2007. Artisanal fisheries and reproductive biology of the golden cownose ray, Rhinoptera steindachneri Everman and Jenkins, 1891, in the Northern Mexican Pacific. Fisheries Research 84, 137-146.

Boyce, W.E.E., Durpia, R.C., 2001. Elementary Differential Equations and Boundary Value Problems, 7th ed. John Wiley \& Sons.

Cinner, J.E., Aswani, S., 2007. Integrating customary management into marine conservation. Biological Conservation 140, 201-216.

Cinti, A. Shaw, W., Cudney-Bueno, R., Rojo, M., 2010. The unintended consequences of format fisheries policies: social disparities and resource overuse in a major fishing community in the Gulf of California, Mexico. Marine Policy 34, 328-339.

Cudney-Bueno, R., Basurto, X., 2009. Lack of cross-scale linkages reduces robustness of community-based fishery management PLOS ONE (Public Library of Science) 4 (7) e6253.

Diario Oficial de la Federación, 1970. 28 de Noviembre de 1970. México, DF, México.

Diario Oficial de la Federación, 1975. 11 de Febrero de 1975. México, DF, México.

Diario Oficial de la Federación, 1978. 2 de Agosto de 1978. México, DF, México.

Dietz, T., Ostrom, E., Stern, P.C., 2003. The struggle to govern the commons. Science 12, $1907-1912$

FAO, 2006. The State of World Fisheries and Aquaculture. Rome, Italy.
Felger, R.S., Moser, M.B., 1985. People of the Desert and Sea. Ethnobotany of the Seri Indians. University of Arizona Press, Tucson.

Garcia-March, J., Garcia-Carrascosa, A., Pena Cantero, A., Wang, Y.G., 2007. Population structure, mortality and growth of Pinna nobilis Linnaeus, 1758 (Mollusca, Bivalvia) at different depths in Moraira bay (Alicante, Western Mediterranean). Marine Biology 150 (5), 861-871.

INEGI. XII Censo general de población y vivienda, 2005. [online] URL: http://www.inegi. gob.mx.

Jackson, J.B.C., Kirby, M.X., Berger, W.H., Bjordal, K.A., Botsford, L.W., Bourque, B.J., Bradbury, R.H., Cooke, R., Erlandson, J., Estes, J.A., Hughes, T.P., Kidwell, S., Lange, C.B., Lenihan, H.S., Pandolfi, J.M., Peterson, C.H., Steneck, R.S., Tegner, M.J., Warner, R.R. 2001. Historical overfishing and the recent collapse of coastal ecosystems. Science 293 629-638.

Johannes, R.E., 1978. Traditional marine conservation methods in Oceania and their demise. Annual Review of Ecology \& Systematics 9, 349-364.

Johannes, R.E., 2002. The renaissance of community-based marine resource management in Oceania. Annual Review of Ecology and Systematics 33, 317-340.

Katsanevakis, S., 2007. Growth and mortality rates of the fan mussel Pinna nobilis in Lake Vouliagmeni (Korinthiakos Gulf, Greece): a generalized additive modeling approach. Marine Biology 152, 1319-1331.

Lansing, J.S., 2006. Perfect Order. Recognizing Complexity in Bali. Princeton University Press, Princeton, USA.

Levin, S., 1999. Fragile Dominion. Perseus, Massachusetts, USA.

Liu, J. Dietz, T. Carpenter, S.R. Alberti, M., Folke, C., Moran, E., Pell, A.N., Deadman, P. Kratz, T., Lubchenco, J., Ostrom, E., Ouyang, Z., Provencher, W., Redman, C.L. Schneider, S.H., Taylor, W.W., 2007a. Complexity of coupled human and natura systems. Science 317 (14), 1513-1516.

Liu, J., Dietz, T., Carpenter, S.R., Folke, C., Alberti, M., Redman, C.L., Schneider, S.H., Ostrom E., Pell, A.N., Lubchenco, J., Taylor, W.W., Ouyang, Z., Deadman, P., Kratz, T., Provencher, W., 2007b. Coupled human and natural systems. AMBIO 36 (8), 639-649.

Mansuri, G., Rao, V., 2004. Community-based and driven development: a critical review. The World Bank Research Observer 19, 1-39.

McCay, B.J., Acheson, J.A. (Eds.), 2006. The question of commons: the culture and ecology of communal resources. University of Arizona Press, Tucson, Arizona.

Moreno, C., Weaver, A., Bourillón, L., Torre, J., Égido, J., Rojo, M., 2005a. Diagnóstico ambiental y socioeconómico de la región marina-costera de Bahía de Kino, Isla Tiburón, Sonora México: Documento de trabajo y discusión para promover un dessarrollo sustentable. Comunidad y Biodiversidad, A.C. Reporte interno. <www. cobi.org $\mathrm{mx}$ /index php?pag=publicaciones\&idioma=esp $>$ (accessed April 2006)

Moreno, C., Torre, J., Bourillón, L., Durazo, M., Weaver, A. H., Barraza, R., Castro, R., 2005b. Estudio y evaluación de la pesquería de callo de hacha (Atrina tuberculosa) en la región de Bahía de Kino, Sonora y recomendaciones para su manejo. Comunidad y Biodiversidad, A.C. Reporte interno. <www.cobi.org.mx/index.php? pag $=$ publicaciones\&idioma $=$ esp $>($ accessed April 2006) .

Myers, R.A., Worm, B., 2003. Rapid worldwide depletion of predatory fish communities. Nature 423, 280-283.

National Research Council, 2002. The drama of the commons. Committee on the Human Dimensions of Global Change. In: Ostrom, E Dietz, T., Dolšak, N. Stern, P.C. Stonich, S., Weber, E.U. (Eds.), Division of behavioral and social sciences and education. National Academy Press, Washington, D.C., USA.

North, D.C., 2005. Understanding the Process of Institutional Change. Princeton University Press, Princeton, NJ.

Orensanz, J.M., Parma, A.M., Jerez, G., Barahona, N., Montecinos, M., Elias, I. 2005. What are the key elements for the sustainability of "S-Fisheries"? Insights from South America. Bulletin of Marine Science 76 (2), 527-556.

Ostrom, E., 1990. Governing the Commons: The Evolution of Institutions for Collective Action. Cambridge University Press, New York, USA

Ostrom, E., 2005. Understanding Institutional Diversity. Princeton University Press, Princeton, USA.

Ostrom, E., 2007. A diagnostic approach for going beyond panaceas. Proceedings of the National Academy of Sciences 104 (39), 15181-15187.

Ostrom, E., Janssen, M.A., Anderies, J.M., 2007. Going beyond panaceas. Proceedings of the National Academy of Sciences 104, 15176-15178.

Pauly, D., Christensen, V., Dalsgaard, J., Froese, R., Torres, F., 1998. Fishing down marine food webs. Science $279,860-863$.

Pinkerton, E. (Ed.), 1989. Co-operative management of local fisheries: new directions for improved management and community development. University of British Columbia Press, Vancouver, Canada.

Richardson, C.A., Kennedy, H., Duarte, C.M., Kennedy, D.P., Proud, S.V., 1999. Age and growth of the fan mussel Pinna nobilis from South-East Spanish Mediterranean seagrass (Posidonia oceanica) meadows. Marine Biology 133, 205-212.

Ruddle, K., Johannes, R.E., 1985. The Traditional Knowledge and Management of Coastal Systems in Asia and the Pacific. UNESCO-ROSTSEA.

Sala, E., Ballesteros, R., Starr, R.M., 2001. Rapid decline of Nassau Grouper spawning aggregations in Belize: fishery management and conservation needs. Fisheries 26, 23-30.

Schlager, E., Ostrom, E., 1992. Property-rights regimes and natural resources: a conceptual analysis. Land Economics 68 (3), 249-262 (August).

Schlager, E., Blomquist, W., Tang, S.Y., 1994. Mobile flows, storage, and self-organized institutions for governing common-pool resources. Land Economics 70, 294-317.

Sheridan, T.E., 1999. Empire of sand. The Seri Indians and the Struggle for Spanish Sonora. The University of Arizona Press, Tucson, AZ, pp. 1645-1803.

Torre-Cosío, J., 2002. Inventory, monitoring and impact assessment of marine biodiversity in the Seri Indian territory, Gulf of California, México. Dissertation. University of Arizona, Tucson, Arizona, USA.

Turner II, B.L., Matson, P.A., McCarthy, J.J., Corell, R.W., Christensen, L., Eckley, N. Hovelsrud-Broda, G.K., Kasperson, J.X., Luers, A., Martello, M.L., Mathiesen, S., 
Naylor, R., Polsky, C., Pulsipher, A., Schiller, A., Selin, H., Tyler, N., 2003. Illustrating the coupled human-environment system for vulnerability analysis: three case studies. Proceedings of the National Academy of Sciences 100 (14), 8080-8085.

Weinstein, M.S., 2000. Pieces of the puzzle: solutions for community-based fisheries management from native Canadians, Japanese cooperatives, and common property researchers. Georgetown International Environmental Law Review (12), 2 Winter.
Wilson, J.A. 2002. Scientific uncertainty, complex systems and the design of common pool institutions. In: Ostrom, E., Dietz, T., Dolšak, N., Stern, P.C., Stonich, S., Weber, E. (Eds.), The Drama of the Commons. National Academy Press, Washington, D.C., USA.

Young, O.R., 2002. The Institutional Dimensions of Environmental Change: Fit, Interplay, and Scale. MIT Press, Cambridge, MA. 